\title{
Targeting myeloid-derived suppressor cells in the treatment of hepatocellular carcinoma: current state and future perspectives
}

This article was published in the following Dove Press journal:

Journal of Hepatocellular Carcinoma

\author{
Li-Chun Lu'-3 \\ Chun-Jung Chang ${ }^{1,2}$ \\ Chih-Hung Hsu ${ }^{\mathrm{I}-3}$ \\ 'Graduate Institute of Oncology, \\ National Taiwan University College of \\ Medicine, Taipei, Taiwan; ${ }^{2}$ Departments \\ of Oncology, National Taiwan University \\ Hospital, Taipei, Taiwan; ${ }^{3}$ Department of \\ Oncology, National Taiwan University \\ Cancer Center, Taipei, Taiwan
}

\begin{abstract}
Systemic therapy for advanced hepatocellular carcinoma (HCC) has been focusing on overcoming tumor angiogenesis and immunosuppression. Myeloid-derived suppressor cells (MDSCs) promote both angiogenesis and immunosuppression in the tumor microenvironment (TME). Multiple clinical studies have demonstrated the prognostic implications of and suggested the translational significance of MDSCs in patients with HCC. In preclinical HCC models, targeting MDSCs has been shown to enhance antitumor efficacy of sorafenib or immune checkpoint inhibitors. Reversing the protumor effects of MDSCs could be achieved by depleting MDSCs, blocking MDSC trafficking and migration into TME, and inhibiting the immunosuppressive functions of MDSCs. To date, these strategies have not yet been validated to be clinically useful in patients with malignancy including HCC. Future studies should focus on identifying specific markers for human MDSCs and developing combination approaches incorporating MDSC-targeting therapy in the treatment of HCC.
\end{abstract}

Keywords: myeloid-derived suppressor cells, MDSCs; hepatocellular carcinoma, immunosuppression, angiogenesis, immunotherapy, immune checkpoint inhibitor

\section{Introduction}

Primary liver cancer, of which the vast majority of cases are hepatocellular carcinoma (HCC), has been the leading cause of cancer mortality worldwide for decades. The GLOBOCAN 2018 database estimated that 841,000 new cases of primary liver cancer and 782,000 deaths from it would occur annually, making it the sixth most commonly diagnosed and fourth most lethal malignancy worldwide. ${ }^{1}$ The carcinogenesis of HCC is attributed to chronic inflammation of the liver, predominantly as a result of hepatitis $\mathrm{B}$ virus (HBV) and hepatitis $\mathrm{C}$ virus (HCV) virus infections, as well as liver cirrhosis. Owing to significant advances in the primary prevention of $\mathrm{HBV}$ infection through universal vaccinations as well as effective antiviral therapy for HBV and HCV infections, the incidence of HCC is expected to decline between 2035 and $2040 .^{2}$ Overall, HCC remains a significant malignant disease that will continue to be a major burden on global health for decades to come.

Treatment of HCC is commonly directed by disease stage. ${ }^{3}$ For patients with early-stage localized HCC, curative-intent treatment modalities include resection, ablation, and liver transplantation, whereas for patients with intermediate-stage localized HCC, image-guided transcatheter tumor therapies such as transarterial chemoembolization have provided survival benefits.
Correspondence: Chih-Hung Hsu Department of Oncology, National Taiwan University Hospital,

7 Chung-Shan South Road, Taipei 10002, Taiwan

Tel +886223I2 3456 ext. 67680

Fax +8862237 I I I74

Email chihhunghsu@ntu.edu.tw
Journal of Hepatocellular Carcinoma 2019:6 7I-84

71 
Unfortunately, the majority of patients with HCC either progress to or develop de novo locally advanced or metastatic diseases and are indicated for systemic therapy.

\section{Recent advances in systemic therapy for HCC}

Sorafenib, a multikinase inhibitor with antiangiogenic properties, is the first systemic therapy approved for HCC owing to two positive randomized placebo-controlled phase III trials. ${ }^{4,5}$ Since 2016, four other antiangiogenic agents, including three multikinase inhibitors and one antivascular endothelial growth factor receptor monoclonal antibody, have been demonstrated to provide survival benefits for patients with advanced HCC in phase III clinical trials (Table 1). ${ }^{6-9}$ As a result, the Food and Drug Administration of the United States (US-FDA) and the regulatory agencies of multiple countries approved lenvatinib as a first-line systemic therapy for HCC, and approved regorafenib and cabozantinib for patients with HCC who have been previously treated with sorafenib.

Moreover, immunotherapy with immune checkpoint inhibitors (ICIs) such as monoclonal antibodies that target programmed cell death protein 1 (PD-1)/programmed deathligand 1 (PD-L1) and cytotoxic T-lymphocyte-associated

Table I Systemic therapy approved or with positive results in phase III trials for advanced hepatocellular carcinoma

\begin{tabular}{|c|c|c|c|c|c|}
\hline $\begin{array}{l}\text { Drug and } \\
\text { study }\end{array}$ & $\begin{array}{l}\text { Mechanism } \\
\text { of action }\end{array}$ & Trial design & $\begin{array}{l}\text { Treatment } \\
\text { arms (patient } \\
\text { numbers) }\end{array}$ & Key findings & $\begin{array}{l}\text { US-FDA } \\
\text { approval }\end{array}$ \\
\hline \multicolumn{6}{|c|}{ Pivotal trials of sorafenib } \\
\hline $\begin{array}{l}\text { Sorafenib, } \\
\text { SHARP trial }\end{array}$ & $\begin{array}{l}\text { Multikinase } \\
\text { inhibitors }\end{array}$ & $\begin{array}{l}\text { Phase III, Ist-line, I:I } \\
\text { randomization }\end{array}$ & $\begin{array}{l}\text { Sorafenib (299) vs } \\
\text { placebo (303) }\end{array}$ & $\begin{array}{l}\text { Median OS: } 10.7 \mathrm{~m} \text { (sorafenib) vs } \\
7.9 \mathrm{~m} \text { (placebo), } \mathrm{HR}=0.69(95 \% \mathrm{Cl} \text {, } \\
0.55-0.87), P<0.00 \mathrm{I}\end{array}$ & 2007 \\
\hline $\begin{array}{l}\text { Sorafenib, Asia- } \\
\text { Pacific trial }{ }^{5}\end{array}$ & $\begin{array}{l}\text { Multikinase } \\
\text { inhibitors }\end{array}$ & $\begin{array}{l}\text { Phase III, Ist-line, 2:I } \\
\text { randomization }\end{array}$ & $\begin{array}{l}\text { Sorafenib (I50) vs } \\
\text { placebo }(76)\end{array}$ & $\begin{array}{l}\text { Median OS: } 6.5 \mathrm{~m} \text { (sorafenib) vs } \\
4.2 \mathrm{~m} \text { (placebo), } \mathrm{HR}=0.68(95 \% \mathrm{Cl} \text {, } \\
0.50-0.93), P=0.014\end{array}$ & 2007 \\
\hline \multicolumn{6}{|c|}{ Antiangiogenic agents } \\
\hline 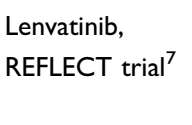 & $\begin{array}{l}\text { Multikinase } \\
\text { inhibitors }\end{array}$ & $\begin{array}{l}\text { Phase III, Ist-line, I:I rando- } \\
\text { mization (noninferiority) }\end{array}$ & $\begin{array}{l}\text { Lenvatinib (478) vs } \\
\text { sorafenib (476) }\end{array}$ & $\begin{array}{l}\text { Median OS: I } 3.6 \mathrm{~m} \text { (lenvatinib) vs } \\
\text { I2.3 m (sorafenib), HR=0.92 (95\% Cl, } \\
0.79-\mid .06)\end{array}$ & 2018 \\
\hline Regorafenib, & Multikinase & Phase III, 2nd-line, 2:I & Regorafenib (379) & Median OS: $10.6 \mathrm{~m}$ (regorafenib) vs & 2017 \\
\hline 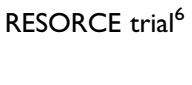 & inhibitors & randomization & vs placebo (194) & $\begin{array}{l}7.8 \mathrm{~m} \text { (placebo), } \mathrm{HR}=0.63(95 \% \mathrm{Cl}, \\
0.50-0.79), P<0.00 \mathrm{I}\end{array}$ & \\
\hline $\begin{array}{l}\text { Ramucirumab, } \\
\text { REACH II trial }\end{array}$ & $\begin{array}{l}\text { Anti-VEGFR } \\
m A b\end{array}$ & $\begin{array}{l}\text { Phase III, 2nd-line, 2:I rando- } \\
\text { mization (AFP } \geq 400 \mathrm{ng} / \mathrm{mL} \text { ) }\end{array}$ & $\begin{array}{l}\text { Ramucirumab } \\
\text { (197) vs placebo } \\
\text { (95) }\end{array}$ & $\begin{array}{l}\text { Median OS: } 8.5 \mathrm{~m} \text { (ramucirumab) vs } \\
7.3 \mathrm{~m} \text { (placebo), HR=0.7। }(95 \% \mathrm{Cl} \text {, } \\
0.53-0.95), P=0.0199\end{array}$ & Pending \\
\hline $\begin{array}{l}\text { Cabozantinib, } \\
\text { CELESTIAL } \\
\text { trial }^{8}\end{array}$ & $\begin{array}{l}\text { Multikinase } \\
\text { inhibitors }\end{array}$ & $\begin{array}{l}\text { Phase III, 2nd- or 3rd-line, 2:I } \\
\text { randomization }\end{array}$ & $\begin{array}{l}\text { Cabozantinib } \\
(470) \text { vs placebo } \\
(237)\end{array}$ & $\begin{array}{l}\text { Median OS: } 10.2 \mathrm{~m} \text { (cabozantinib) vs } \\
8.0 \mathrm{~m} \text { (placebo), } \mathrm{HR}=0.76(95 \% \mathrm{Cl} \text {, } \\
0.63-0.92), P=0.009\end{array}$ & 2019 \\
\hline \multicolumn{6}{|c|}{ Immune checkpoint inhibitors } \\
\hline $\begin{array}{l}\text { Nivolumab, } \\
\text { CheckMate } 040 \\
\text { trial }^{10}\end{array}$ & Anti-PD-I mAb & $\begin{array}{l}\text { Phase } 1 / I I, \text { multicohort, Both } \\
\text { Ist- and } 2 \text { nd-lines ( } 70 \% \text { pre- } \\
\text { viously treated with sorafenib) }\end{array}$ & $\begin{array}{l}\text { Nivolumab: dose- } \\
\text { escalation (48); } \\
\text { dose-expansion } \\
(2 \mid 4)\end{array}$ & $\begin{array}{l}\text { ORR: } 20 \%(95 \% \mathrm{Cl}, 15-26) \text { in the } \\
\text { dose-escalation and } 15 \%(95 \% \mathrm{Cl} \text {, } \\
6-28) \text { in the dose-expansion cohorts }\end{array}$ & $2017^{*}$ \\
\hline $\begin{array}{l}\text { Pembrolizumab, } \\
\text { Keynote-224 } \\
\text { trial }^{11}\end{array}$ & Anti-PD-I mAb & Phase II, 2nd-line & $\begin{array}{l}\text { Pembrolizumab } \\
\text { (104) }\end{array}$ & ORR: $17 \%(95 \% \mathrm{Cl}, \mathrm{II}-26)$ & $2018^{*}$ \\
\hline
\end{tabular}

Note: *Accelerated approval.

Abbreviations: US-FDA, Food and Drug Administration of the United States; OS, overall survival; m, months; HR, hazard ratio; VEGFR, vascular endothelial growth factor receptor; mAb, monoclonal antibody; PD-I, programmed cell death protein I; AFP, $\alpha$-fetoprotein; ORR, objective response rate. 
antigen 4 (CTLA-4) has become a new paradigm of treatment for multiple cancers, including HCC. Nivolumab, an anti-PD-1 monoclonal antibody, induced a considerable and durable objective tumor response in patients with advanced HCC in a phase I/II study. ${ }^{10}$ Pembrolizumab, another antiPD-1 monoclonal antibody, exhibited a similar response rate (RR) to nivolumab in patients with $\mathrm{HCC}$ who had previously been treated with sorafenib in a phase II study. ${ }^{11}$ Nivolumab and pembrolizumab were granted accelerated approval for the treatment of HCC in 2017 and 2018, respectively, by the US-FDA (Table 1).

Overall, two classes of drugs now exist to treat patients with advanced HCC: one targets tumor angiogenesis and the other targets immunosuppression. Tumor angiogenesis and immune evasion are two major "cancer hallmarks". 12,13 Efforts have been ongoing to develop strategies that combine antiangiogenic therapy with PD-1/PD-L1 inhibitors in patients with advanced HCC. ${ }^{14-16}$ However, new studies that elucidate the mechanisms underlying angiogenesis promotion and immunosuppression of HCC may help inspire the development of new therapeutic strategies in the future.

\section{Myeloid-derived suppressor cells: dual tumor-supporting effects by promoting immunosuppression and angiogenesis}

Myeloid-derived suppressor cells (MDSCs) play a critical role in the immune tumor microenvironment (TME). MDSCs represent a heterogeneous population of immature myeloid cells with various states of differentiation and are distributed in the bone marrow, spleen, peripheral blood, and tumor tissues. MDSCs have various functions that support tumor growth, including the suppression of T and NK cells and the promotion of angiogenesis. Therefore, targeting MDSCs is a potential strategy for enhancing the current treatment of cancers. ${ }^{17}$

In both humans and mice, MDSCs have two major types: monocytic MDSCs (M-MDSCs) and granulocytic or polymorphonuclear MDSCs (PMN-MDSCs). M-MDSCs share morphological characteristics with monocytes, whereas PMNMDSCs present morphological characteristics of neutrophils (Table 2). In most cancers, PMD-MDSCs are predominant, representing approximately three-fourths of all MDSCs. In mice, MDSCs are defined using surface markers CD11b and Gr1, and Gr1 has shared epitopes with Ly6C and Ly6G, which are expressed in monocytic cells and granulocytes, respectively. Therefore, M-MDSCs are defined as $\mathrm{CD}_{11 \mathrm{~b}^{+} \text {Ly6G }}$ Ly6C $^{\text {high }}$ cells and PMN-MDSCs are defined as $\mathrm{CD} 11 \mathrm{~b}^{+} \mathrm{Ly}_{6 \mathrm{G}}{ }^{\text {high }} \mathrm{Ly} 6 \mathrm{C}^{\text {low }}$ cells in mice. In human, MDSCs generally lack HLA-DR expression, and M-MDSCs are

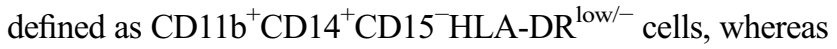
PMN-MDSCs are defined as CD $11 \mathrm{~b}^{+} \mathrm{CD} 14^{-} \mathrm{CD} 15^{+} \mathrm{HLA}_{-D R}$

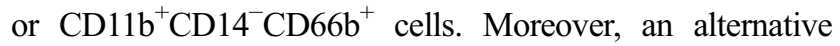
immature cell subset in humans that is defined by a lack of lineage markers, including CD3, CD14, CD15, CD19, CD56, and HLA-DR, and the expression of CD33 is named earlystage MDSCs. ${ }^{18}$ Recently, Condamine et al identified lectintype oxidized LDL receptor-1 (LOX-1) as a new marker for PMN-MDSCs in humans, further facilitating the discrimination of human PMN-MDSCs from mature neutrophils. ${ }^{19}$

Immunosuppression is the primary feature of MDSCs. Although MDSCs suppress diverse immune cells, their main immunosuppressive mechanisms are the inhibition of $\mathrm{T}$ cells and NK cells and induction of regulatory $\mathrm{T}$ cells (Treg). The major factors involved in MDSC-mediated immunosuppression include arginase (ARG1), inducible nitric oxide synthase (iNOS), reactive oxygen species (ROS), TGF- $\beta$, IL-10, COX2, indoleamine 2,3-dioxygenase (IDO), and others. ${ }^{17,20}$ ARG1

Table 2 Two major types of myeloid-derived suppressor cells and their immunosuppressive functions

\begin{tabular}{|c|c|c|c|c|}
\hline Types & Markers in mice & Markers in human & $\begin{array}{l}\text { Main factors med- } \\
\text { iating immunosup- } \\
\text { pression }\end{array}$ & $\begin{array}{l}\text { Mechanisms of } \\
\text { immunosuppression }\end{array}$ \\
\hline M-MDSCs & CDI Ib ${ }^{+}{ }^{2} 6 G^{-}$Ly6C high & 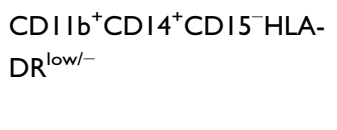 & $\begin{array}{l}\text { NO, ARGI, and cytokines } \\
\text { such as TGF- } \beta \text { and IL-10 }\end{array}$ & $\begin{array}{l}\text { Suppress T-cell responses both in antigen- } \\
\text { specific and nonspecific manners; produc- } \\
\text { tion of NO and cytokines }\end{array}$ \\
\hline $\begin{array}{l}\text { PMN- } \\
\text { MDSCs }\end{array}$ & CD I I b ${ }^{+}$Ly6G ${ }^{\text {high }}$ Ly6C low & $\begin{array}{l}\mathrm{CDI} / \mathrm{b}^{+} \mathrm{CD} / 4^{-} \mathrm{CD} / 5^{+} \mathrm{HLA}- \\
\mathrm{DR}^{-} \text {or } \\
\mathrm{CDII} \mathrm{b}^{+} \mathrm{CD} / 4^{-} \mathrm{CD} 66 \mathrm{~b}^{+} \text {or } \\
\mathrm{LOX}^{+} \mathrm{I}^{+}\end{array}$ & ROS, ARGI & $\begin{array}{l}\text { Suppressing immune responses primarily in } \\
\text { an antigen-specific manner; ROS production }\end{array}$ \\
\hline
\end{tabular}

Abbreviations: M-MDSCs, monocytic myeloid-derived suppressor cells; NO, nitric oxide; ARGI, arginase; PMN-MDSCs, polymorphonuclear myeloid-derived suppressor cells. 
depletes L-arginine and leads to cell cycle arrest in the G0-G1 phase of tumor-infiltrating $\mathrm{T}$ cells. Depleted L-arginine, increased NO production by iNOS, and increased ROS all result in the downregulation or desensitization of the T-cell receptor and induction of T-cell anergy. IDO degrades L-tryptophan and leads to the suppression of T and NK cells and activation of Treg. ${ }^{20}$ Studies have also suggested that the immunosuppressive mechanisms of MDSCs may vary at different sites. In peripheral lymphoid structures, PMN-MDSCs have a high level of ROS production and suppress $\mathrm{T}$ cells function in an antigen-specific manner. By contrast, M-MDSCs suppress not only antigen-specific but also nonspecific T-cell responses by expressing various factors such as ARG1, NO, TGF- $\beta$, and IL-10. In TME, because of hypoxia, ROS levels in PMN-MDSCs are substantially reduced; however, the levels of ARG1 and other factors responsible for nonspecific T-cell suppression are increased. ${ }^{17}$

Additionally, MDSCs influence TME by inducing tumor angiogenesis through the production of several angiogenic factors and vascular-modulating enzymes. ${ }^{21}$ For example, Bv8 (bombina variegata peptide 8, a homolog of endocrine-gland-derived vascular endothelial growth factor), produced by MDSCs through granulocyte colony-stimulating factor (G-CSF)-dependent STAT3 signaling, was demonstrated to promote angiogenesis and hematopoietic cell mobilization. ${ }^{22}$ Actually, MDSC accumulation in TME was associated with tumor refractoriness to anti-VEGF treatment; anti-G-CSF therapy or anti-Bv8 therapy could enhance the responsiveness of anti-VEGF treatment. $^{23,24}$ Moreover, matrix metalloproteinase-9 (MMP-9)-expressing CD11 ${ }^{+}$myelomonocytic cells have been shown to be critical for the formation of tumor vasculature. Tumor growth could be inhibited in MMP-9 knockout mice or by the deletion of MMP-9 in $\mathrm{CD}_{11 \mathrm{~b}^{+} \mathrm{Gr} 1^{+}} \mathrm{MDSCs}^{25,26}$ In addition, MDSCs could acquire endothelial cell properties in TME and directly incorporate into tumor endothelium. ${ }^{26}$

\section{Clinical significance of MDSCs in human HCC}

Previous studies have demonstrated the role of MDSCs in various chronic liver diseases such as HBV or HCV-related hepatitis, and non-alcoholic fatty liver disease (NAFLD). ${ }^{27-30}$ MDSCs were shown to inhibit $\mathrm{T}$ cells and moderate HBV-related liver damage during viral replication through ARG1-dependent manner. ${ }^{27}$ MDSCs may protect liver from detrimental necroinflammation, but also contribute to persistence of $\mathrm{HBV}$ infection. ${ }^{31} \mathrm{HCV}$ infection could induce MDSCs, which suppressed T cells and antiviral NK cell responses via ROS and ARG1. ${ }^{28,29}$ Moreover, MDSCs accumulated in the livers of NAFLD mice and had strong suppression effect on $\mathrm{T}$ cells, which was dependent on NO production by iNOS. ${ }^{30}$

Clinical studies of MDSCs in HCC have mainly focused on analyzing M-MDSCs in the peripheral blood of patients with HCC, probably because the cryopreservation process may negatively affect PMN-MDSCs. ${ }^{32}$ Several groups have studied M-MDSCs, defined by CD14 ${ }^{+} \mathrm{HLA}_{-\mathrm{DR}}^{-/ \text {low }}$ cells, in the peripheral blood mononuclear cells (PBMCs) of patients with HCC. They found that these MDSCs increased in the PBMCs of patients with HCC compared with patients with only hepatitis or cirrhosis and healthy controls. ${ }^{33-35}$ Moreover, a high frequency of MDSCs in PBMCs has been associated with aggressive tumor features and poor clinical outcomes after hepatectomy, local ablation, or hepatic arterial infusion chemotherapy. ${ }^{34-36}$ Another report defined MDSCs as $\mathrm{CD}_{3}{ }^{+} \mathrm{HLA}_{-\mathrm{DR}}{ }^{\text {low/-}} \mathrm{CD} 11 \mathrm{~b}^{+} \mathrm{CD} 14^{+}$cells, and found PD- $1^{+}$MDSCs to be increased in the PBMCs of patients with HCC. In addition, tumor-infiltrating leukocytes contained markedly higher percentages of PD-L1 ${ }^{+}$MDSCs than liver-infiltrating leukocytes and PBMCs. ${ }^{37}$ Mechanistically, M-MDSCs isolated from the PBMCs of patients with HCC have been proven to be immunosuppressive, as well as shown to have high ARG1, suppress autologous $\mathrm{T}$ cell proliferation, inhibit autologous NK cell cytotoxicity, and induce Tregs when cultured ex vivo. ${ }^{33,38}$

Other studies have utilized various markers to define MDSCs in circulation in patients with HCC. Kalathil et al measured multiple immunosuppressive factors in $\mathrm{HCC}$, and found that the frequency of CD14 HLA-DR

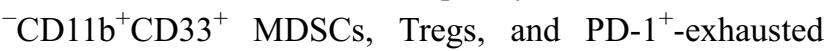
$\mathrm{T}$ cells as well as immunosuppressive cytokines levels were increased in the peripheral blood of patients with HCC compared with healthy donors. Combined depletion of MDSCs, Tregs, and PD- $1^{+}$-exhausted $\mathrm{T}$ cells in PBMCs isolated from patients with advanced HCC restored the production of granzyme $\mathrm{B}$ by $\mathrm{CD}^{+} \mathrm{T}$ cells in vitro. ${ }^{39}$ Recently, Nan et al employed a novel marker, LOX-1, to analyze PMN-MDSCs in patients with HCC and determined that $\mathrm{LOX}-1^{+} \mathrm{CD} 15^{+}$cells were significantly increased in the PBMCs of patients with $\mathrm{HCC}$ compared with patients with hepatitis or cirrhosis and healthy controls. The levels of $\mathrm{LOX}-1^{+} \mathrm{CD} 15^{+} \mathrm{PMN}-$ MDSCs in circulation were associated with those 
identified in HCC tissues. LOX- $1^{+} \mathrm{CD} 15^{+}$PMN-MDSCs suppressed the proliferation and interferon (IFN)- $\gamma$ production of $\mathrm{T}$ cells in vitro, whereas the $\mathrm{LOX}-1^{-} \mathrm{CD} 15^{+}$ PMNs did not. ${ }^{40}$
Table 3 summarizes the results of studies on MDSCs in patients with HCC, emphasizing the immunosuppressive activities and prognostic implications of MDSCs.

Table 3 Previous clinical studies on myeloid-derived suppressor cells in hepatocellular carcinoma

\begin{tabular}{|c|c|c|c|c|}
\hline Studies & $\begin{array}{l}\text { Markers in } \\
\text { humans }\end{array}$ & $\begin{array}{l}\text { HCC } \\
\text { patient } \\
\text { no. }\end{array}$ & Key findings & $\begin{array}{l}\text { Mechanistic insight or transla- } \\
\text { tional implication }\end{array}$ \\
\hline $\begin{array}{l}\text { Hoechest et al } \\
\text { Gastroenterology } 2008^{33}\end{array}$ & $\mathrm{CDI}^{+}{ }^{+} \mathrm{HLA}-\mathrm{DR}^{-/ \text {low }}$ & 111 & $\begin{array}{l}\text { The frequency of MDSCs increased in } \\
\text { PBMCs compared with healthy donors } \\
\text { or cirrhosis patients. }\end{array}$ & $\begin{array}{l}\text { MDSCs suppress T-cell proliferation and } \\
\text { induce Treg. }\end{array}$ \\
\hline $\begin{array}{l}\text { Hoechst et al } \\
\text { Hepatol } 2009^{38}\end{array}$ & $\mathrm{CDI} / 4^{+} \mathrm{HLA}-\mathrm{DR}{ }^{-/ l o w}$ & 30 & $\begin{array}{l}\text { MDSCs inhibited NK cell cytotoxicity } \\
\text { and IFN- } \gamma \text { release in vitro. }\end{array}$ & $\begin{array}{l}\text { Suppression of NK cells by MDSCs was } \\
\text { dependent on cell contact but indepen- } \\
\text { dent of ARGI or iNOS function. } \\
\text { MDSCs inhibited NK cell function via } \\
\text { the NKp30 receptor on NK cells. }\end{array}$ \\
\hline $\begin{array}{l}\text { Arihara et al } \\
\text { Cancer Immunol } \\
\text { Immunother } 2013^{34}\end{array}$ & $\mathrm{CDI} 4^{+} \mathrm{HLA}_{-} \mathrm{DR}^{-/ \text {low }}$ & 123 & $\begin{array}{l}\text { The frequency of MDSCs in CDI } 4^{+} \\
\text {PBMCs was significantly increased in } \\
\text { patients with HCC compared with that } \\
\text { in non-HCC controls. }\end{array}$ & $\begin{array}{l}\text { The frequency of MDSCs was signifi- } \\
\text { cantly decreased after RFA ( } 33 \\
\text { patients). Patients with high frequency } \\
\text { of MDSCs after RFA had worse RFS } \\
\text { than those with low frequency of } \\
\text { MDSCs after RFA. }\end{array}$ \\
\hline $\begin{array}{l}\text { Mizukoshi et al } \\
\text { Cancer Immunol } \\
\text { Immunother } 2016^{36}\end{array}$ & $\mathrm{CD} / 4^{+} \mathrm{HLA}^{-D R^{-}}$ & 36 & $\begin{array}{l}\text { High frequency of MDSCs in PBMCs } \\
\text { was associated with aggressive tumor } \\
\text { features such as advanced stage, large } \\
\text { tumor size, main PVT, and distant } \\
\text { metastasis. }\end{array}$ & $\begin{array}{l}\text { A low frequency of MDSCs was asso- } \\
\text { ciated with tumor response and longer } \\
\text { OS in patients with advanced HCC } \\
\text { receiving HAIC. }\end{array}$ \\
\hline $\begin{array}{l}\text { Gao et al } \\
\text { Hepatology Res } 2017^{35}\end{array}$ & $\mathrm{CDI}^{+} 4^{+} \mathrm{LA}-\mathrm{DR}^{-/ \text {low }}$ & 183 & $\begin{array}{l}\text { The frequency of MDSCs increased in } \\
\text { PBMCs of HCC patients compared with } \\
\text { those of chronic hepatitis and healthy } \\
\text { donors. }\end{array}$ & $\begin{array}{l}\text { High MDSCs were associated with early } \\
\text { recurrence and poor OS after } \\
\text { hepatectomy. }\end{array}$ \\
\hline $\begin{array}{l}\text { Iwata et al } \\
\text { Sci Rep } 2016^{37}\end{array}$ & 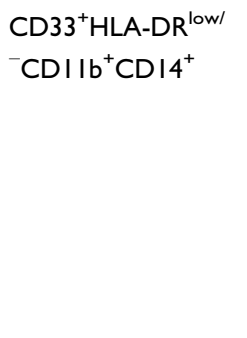 & 122 & $\begin{array}{l}\text { PD-LI }{ }^{+} \text {MDSCs were increased in } \\
\text { PBMCs from patients with HCC. TILs } \\
\text { contained remarkably higher percen- } \\
\text { tages of PD-LI }{ }^{+} \text {MDSCs than liver- } \\
\text { infiltrating lymphocytes and PBMCs (I4 } \\
\text { patients with HCC). }\end{array}$ & $\begin{array}{l}\text { The percentages of PD-LI+MDSCs in } \\
\text { PB were significantly reduced by cura- } \\
\text { tive treatment for HCC ( } 12 \text { patients } \\
\text { with } \mathrm{HCC} \text { ). Patients with low PD- } \\
\mathrm{LI}^{+} \mathrm{MDSC} \text { in PB before curative treat- } \\
\text { ment had significantly longer DFS than } \\
\text { those with high PD-LI+MDSCs ( } 55 \\
\text { patients with HCC). }\end{array}$ \\
\hline $\begin{array}{l}\text { Kalathil et al } \\
\text { Cancer Res } 2013^{39}\end{array}$ & $\begin{array}{l}\mathrm{CD} / 4^{-} \mathrm{HLA}-\mathrm{DR} \\
{ }^{-} \mathrm{CDIII}^{+} \mathrm{CD} 33^{+}\end{array}$ & 23 & $\begin{array}{l}\text { The frequency and absolute number of } \\
\text { circulating MDSCs was significantly ele- } \\
\text { vated in patients with HCC. }\end{array}$ & $\begin{array}{l}\text { Depleting Tregs, MDSCs, and PD }-\mathrm{I}^{+} \\
\mathrm{T} \text { cells of patients with advanced } \mathrm{HCC} \\
\text { restored production of granzyme B by } \\
\mathrm{CD} 8^{+} \mathrm{T} \text { cells in vitro. }\end{array}$ \\
\hline $\begin{array}{l}\text { Nan et al } \\
\text { Immunology } 2018^{40}\end{array}$ & $\mathrm{LOX}_{-1}{ }^{+} \mathrm{CD} / 5^{+}$ & 127 & $\begin{array}{l}\text { MDSCs in PBMCs were significantly } \\
\text { elevated in patients with HCC com- } \\
\text { pared with healthy controls. }\end{array}$ & $\begin{array}{l}\text { MDSCs significantly reduced prolifera- } \\
\text { tion and IFN- } \gamma \text { production of T cells } \\
\text { in vitro through the ROS/ARGI path- } \\
\text { way induced by ER stress. }\end{array}$ \\
\hline
\end{tabular}

Abbreviations: HCC, hepatocellular carcinoma; MDSCs, myeloid-derived suppressor cells; PBMCs, peripheral blood mononuclear cells; Treg, regulatory T cells; NK cell, natural killer cell; IFN- $\gamma$, interferon- $\gamma$; ARGI, arginase; iNOS, inducible nitric oxide synthase; RFA, radiofrequency ablation; RFS, recurrence-free survival; PVT, portal vein thrombosis; OS, overall survival; HAIC, hepatic arterial infusion chemotherapy; PD-LI, programmed death-ligand I; TILs, tumor-infiltrating leukocytes; PB, peripheral blood; DFS, disease-free survival; PD-I, programmed cell death protein I; ER, endoplasmic reticulum. 


\section{Biological significance of MDSCs in experimental models of HCC}

Multiple mouse HCC models have demonstrated that MDSCs are present at an increased level in tumor-bearing mice and accumulate in HCCs. In orthotopic and subcutaneous tumors derived from the mouse HCC cell line RIL175 , MDSCs rapidly expanded in the liver, spleen, and blood, whereas in slow-growing diethylnitrosamine-induced HCC and MYC-expressing spontaneous HCC models, MDSCs were increased in more advanced stages. ${ }^{41}$ Some studies using transplantable HCC models have demonstrated that MDSCs not only inhibit $\mathrm{T}$ and NK cells but also suppress the $T$ cell stimulating activity of dendritic cells and alter Kupffer cell function. ${ }^{42,43}$ Collectively, these results illustrate the roles of MDSCs playing in the development and progression of mouse HCCs.

Other preclinical studies have explored the significance of MDSCs in TME of mouse HCCs while investigating the therapeutic effect of sorafenib. Chen et al demonstrated that sorafenib-induced tumor hypoxia and stroma-derived factor 1 alpha (SDF1- $\alpha$ ) expression, which subsequently induced $\mathrm{CD}_{1} 1 \mathrm{~b}^{+} \mathrm{Gr} 1^{+}$MDSC-infiltration in an HCA-1 orthotopic mouse liver cancer model. Furthermore, $\mathrm{CD}_{1} 1 \mathrm{~b}^{+} \mathrm{Gr} 1^{+}$MDSCs mediated the resistance of sorafenib in liver tumors by promoting hepatic stellate cell differentiation and survival and inducing tumor fibrosis. Inhibiting C-X-C receptor type 4 (CXCR4), the receptor of SDF1- $\alpha$, or targeting Gr-1 improved the therapeutic effect of sorafenib by reducing the growth of mouse HCCs. $^{44}$ Our group studied another orthotopic HCC model using BNL mouse liver cancer cells and found that tumor-infiltrating $\mathrm{Ly}_{6 \mathrm{G}}{ }^{+}$PMN-MDSCs increased in mouse HCCs treated with sorafenib. Ly6G ${ }^{+}$MDSCs suppressed $\mathrm{T}$ cell proliferation, induced IL-10 or TGF- $\beta$ expressing $\mathrm{CD}^{+} \mathrm{T}$ cells, and downregulated the cytotoxic activity of $\mathrm{CD} 8^{+} \mathrm{T}$ cells. Multiple proinflammatory and proangiogenic factors, including G-CSF, stroma-derived factor (SDF), TGF- $\beta$, tumor necrosis factor (TNF)- $\alpha$, VEGF, IL-1 $\beta$, and IL-6 were found to be increased in sorafenib-treated mouse orthotopic liver tumors. Targeting MDSCs with anti-Ly6G or anti-IL-6 antibody significantly reduced the frequency of $\mathrm{Ly} 6 \mathrm{G}^{+}$MDSCs in orthotopic liver tumors, enhanced $\mathrm{T}$ cell proliferation, and improved the therapeutic effect of sorafenib. ${ }^{45}$

Recent studies have investigated the roles of MDSCs in the efficacy of ICIs in mouse HCC models. Chiu et al studied multiple orthotopic mouse HCC models and found tumor hypoxia induced the ectoenzyme, ectonucleoside triphosphate diphosphohydrolase 2 (ENTPD2), by stabilizing HIF-1 in cancer cells. ENTPD2 supported the maintenance of MDSCs, and targeting ENTPD2 inhibited tumor growth and enhanced the efficacy of PD-1/CTLA4 blockade. ${ }^{46}$ Zhou et al demonstrated that the overexpression of cell cycle-related kinase (CCRK), a cyclindependent kinase family member, increased MDSC accumulation and $\mathrm{T}$ cell suppression in liver-specific CCRKinducible transgenic mice. Targeting CCRK or downstream IL-6 signaling reduced tumor-infiltrating MDSCs and increased intratumoral IFN- $\gamma^{+} \mathrm{TNF}-\alpha^{+} \mathrm{CD} 8^{+} \mathrm{T}$ cells. Furthermore, the inhibition of CCRK enhanced the antitumor effect of anti-PD-L1 therapy. ${ }^{47}$

Overall, preclinical studies using mouse liver cancer models not only confirmed the roles of MDSCs in tumor formation and progression but also indicated the effects of MDSCs in the treatment efficacies of sorafenib and ICIs against HCCs (Table 4). Most studies have indicated that targeting MDSCs would improve the efficacy of sorafenib or ICIs - the currently approved therapeutic agentsin HCC.

\section{Targeting MDSCs in the treatment of human HCC: clinical evidence to date}

Numerous preclinical studies have investigated targeting MDSCs as a therapeutic strategy to improve tumor control in experimental animal models. Reversing the protumor effects of MDSCs could be achieved by depleting MDSCs, blocking MDSC trafficking and migration into TME, and inhibiting the immunosuppressive function of MDSCs (Figure 1). The scientific rationales and potential approaches of targeting MDSCs as cancer treatment have been previously reviewed by several groups. ${ }^{17,48-50}$ Herein, we discuss the clinical data concerning HCC by focusing on agents or approaches that have been directly or indirectly implicated in targeting MDSCs in preclinical studies.

\section{Depletion of MDSCs}

The number of MDSCs of cancer-bearing hosts could be reduced by inhibiting the myelopoiesis of bone marrow and inducing apoptosis of MDSCs; both these effects are commonly induced by chemotherapeutic agents. Indeed, several chemotherapeutic agents, including gemcitabine, 
Table 4 Recent preclinical studies of myeloid-derived suppressor cells in experimental hepatocellular carcinoma models

\begin{tabular}{|c|c|c|c|}
\hline Studies & Preclinical models & Key findings & $\begin{array}{l}\text { Mechanistic insight or transla- } \\
\text { tional implication }\end{array}$ \\
\hline \multicolumn{4}{|c|}{ Inducing immunosuppression } \\
\hline $\begin{array}{l}\text { Hu et al } \\
\text { Scand } \\
\text { J Gastroenterol } 2011^{42} \\
\text { Lacotte et al } \\
\text { Oncoimmunology } 2016^{4-} \\
3\end{array}$ & $\begin{array}{l}\text { RIL-I75 orthotopic mouse } \\
\text { liver cancer models }\end{array}$ & $\begin{array}{l}\text { Increased frequency of MDSCs in tumor } \\
\text { development was detected in spleen, PB, } \\
\text { LN, and tumor, and IL-I0 levels were } \\
\text { higher in MDSCs derived from tumor- } \\
\text { bearing mice than in control. } \\
\text { Kupffer cells expressed less costimulatory } \\
\text { CD86 and MHCII and more coinhibitory } \\
\text { CD274 molecules in HCC-bearing livers } \\
\text { than in control livers, indicating decreased } \\
\text { antigen-presenting activity. }\end{array}$ & $\begin{array}{l}\text { MDSCs inhibited TLR-ligand-induced IL-I } 2 \\
\text { production of DC through IL- } 10 \text { produc- } \\
\text { tion and suppressed T cell stimulatory } \\
\text { activity of DC. } \\
\text { MDSC subsets (Ly6G }{ }^{\text {high }} \text { cells, GrI }{ }^{\text {high }} \text { cells, } \\
\text { and Ly6C }{ }^{\text {low }} \text { cells) were identified and } \\
\text { sorted from HCC-bearing mice. Primary } \\
\text { isolated Kupffer cells in co-cultured with } \\
\text { the three MDSC subsets showed } \\
\text { a decrease in CCL2 and IL- } 18 \text { secretion, } \\
\text { increase in IL-I0 and IL-Ib secretion, and } \\
\text { increased expression of CD86, CD274, } \\
\text { and MHCII. }\end{array}$ \\
\hline \multicolumn{4}{|c|}{ Engaging drug efficacy } \\
\hline $\begin{array}{l}\text { Chang et al } \\
\text { Int J Cancer } 2018^{45}\end{array}$ & $\begin{array}{l}\text { BNL orthotopic mouse liver } \\
\text { cancer models }\end{array}$ & $\begin{array}{l}\text { Sorafenib induced tumor-infiltration of } \\
\text { CDIIb+GrI }{ }^{+} \text {MDSCs through SDFI- } \alpha / \\
\text { CXCR4 signaling. }\end{array}$ & $\begin{array}{l}\text { CDII }{ }^{+} \mathrm{GrI}^{+} \text {MDSCs mediated the resis- } \\
\text { tance of sorafenib in liver tumors by pro- } \\
\text { moting hepatic stellate cell differentiation } \\
\text { and survival and inducing tumor fibrosis. } \\
\text { Inhibition of CXCR4 or Gr-I in combina- } \\
\text { tion with sorafenib inhibited HCC growth } \\
\text { compared with sorafenib alone. } \\
\text { Targeting MDSCs with anti-Ly6G or anti-IL } \\
-6 \text { antibodies improved antitumor efficacy } \\
\text { of sorafenib. }\end{array}$ \\
\hline $\begin{array}{l}\text { Chiu et al } \\
\text { Nat Commun } 2017^{46}\end{array}$ & $\begin{array}{l}\text { MHCC97L cells and Hepal- } \\
6 \text { orthotopic mouse liver } \\
\text { cancer models }\end{array}$ & $\begin{array}{l}\text { Hypoxia, through stabilization of HIF-I, } \\
\text { induced ENTPD2/CD39LI expression in } \\
\text { cancer cells. }\end{array}$ & $\begin{array}{l}\text { Overexpression of ENTPD2 was a poor } \\
\text { prognostic factor for patients with HCC. } \\
\text { In mouse models, ENTPD2 promoted the } \\
\text { maintenance of MDSCs by preventing their } \\
\text { differentiation. ENTPD2 inhibition was able } \\
\text { to mitigate cancer growth and enhance the } \\
\text { efficacy of immune checkpoint inhibitors. }\end{array}$ \\
\hline $\begin{array}{l}\text { Zhou et al } \\
\text { Gut } 2018^{47}\end{array}$ & $\begin{array}{l}\text { Liver-specific CCRK- } \\
\text { inducible transgenic mice } \\
\text { and Hepal- } 6 \text { orthotopic } \\
\text { mouse liver cancer models }\end{array}$ & $\begin{array}{l}\text { Ccrk-IL-6 signaling drove liver tumorigeni- } \\
\text { city through MDSC immunosuppression. }\end{array}$ & $\begin{array}{l}\text { Targeting tumorous CCRK signaling } \\
\text { diminished MDSC-mediated immunosup- } \\
\text { pression and inhibited tumorigenicity of } \\
\text { HCC. Tumorous CCRK depletion upregu- } \\
\text { lated PD-LI expression and increased } \\
\text { intratumoral CD8 }{ }^{+} \text {T cells, thereby } \\
\text { enhancing PD-LI blockade efficacy to era- } \\
\text { dicate HCC. }\end{array}$ \\
\hline
\end{tabular}

Abbreviations: MDSCs, myeloid-derived suppressor cells; PB, peripheral blood; LN, lymph node; HCC, hepatocellular carcinoma; TLR, Toll-like receptor; DC, dendritic cell; MHC, major histocompatibility complex; HIF-I, hypoxia-inducible factor-I; ENTPD2, ectonucleoside triphosphate diphosphohydrolase 2; CCRK, cell cycle-related kinase; PD-LI, programmed death-ligand I.

doxorubicin, paclitaxel, and 5-fluorouracil (5-FU), have been investigated in preclinical studies and demonstrated to reduce the number of MDSCs in circulation and in TME. ${ }^{51-54}$ Clinical trials conducted a decade or two ago, most of which were small-scale single-arm phase II trials, demonstrated objective tumor RRs ranging from $0 \%$ to $33 \%$ for the aforementioned agents in patients with advanced HCC. ${ }^{55-62}$ However, the successful use of 


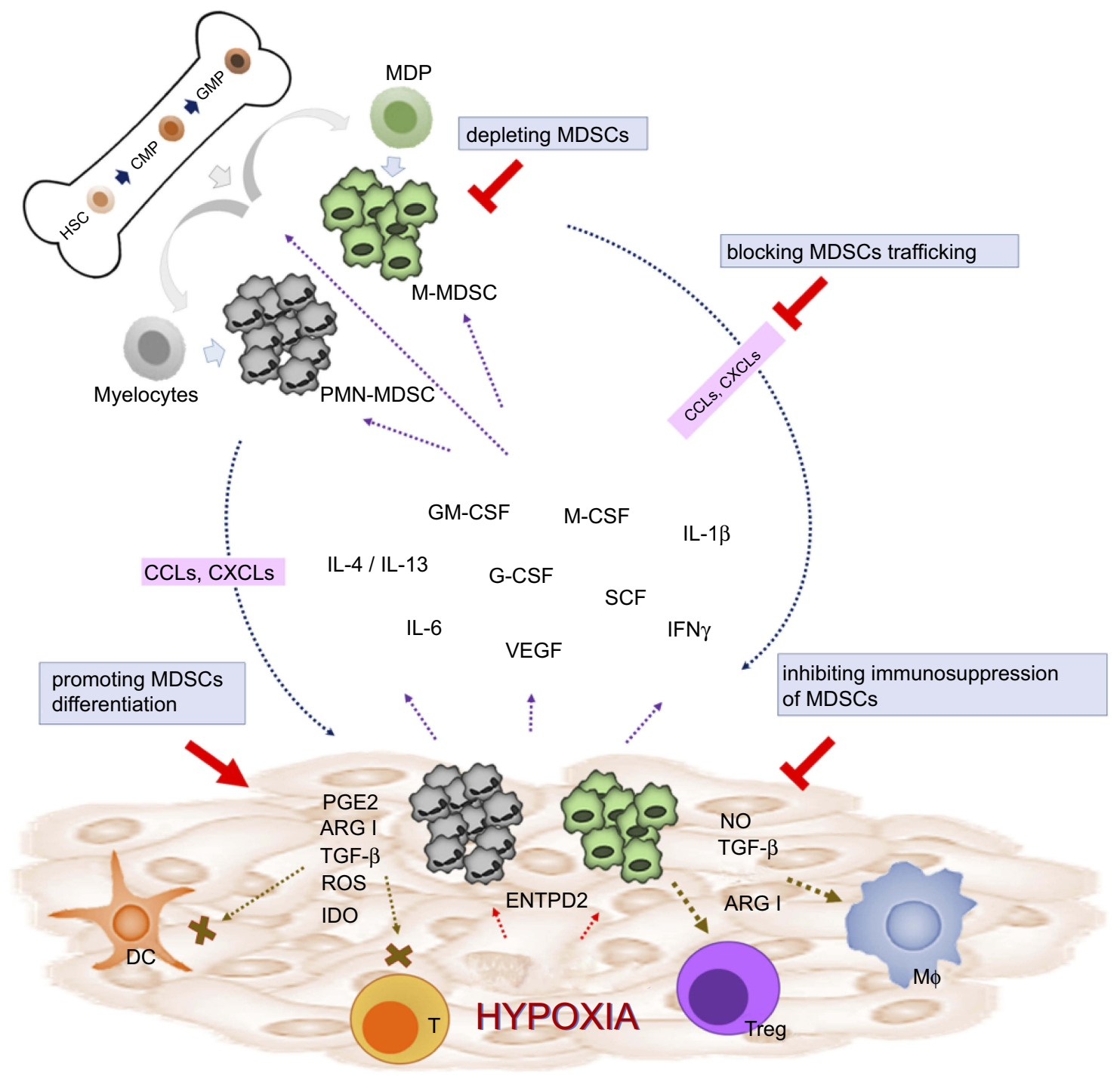

Figure I Strategies of targeting MDSCs in cancers. In physiological condition, HSCs differentiate into CMPs and GMPs, which subsequently become mature granulocytes or monocytes. In pathological condition such as malignancy, multiple tumor-derived factors affect the differentiation of myeloid cells, leading to the generation M-MDSCs and PMN-MDSCs. Both types of MDSCs migrate to the tumor site through the interaction of chemokine receptors and ligands (CCLs or CXCLs). In TME, MDSCs are activated and can support tumor growth by suppressing antitumor response of T cells through various mechanisms such as ARGI, iNOS, ROS, TGF- $\beta$, IL-I0, and IDO. MDSCs can also promote macrophage polarization and induce Tregs and tolerogenic DCs. Reversing the protumor effects of MDSCs could be achieved by depleting MDSCs, promoting MDSC differentiation, blocking MDSC trafficking and migration into TME, and inhibiting the immunosuppressive function of MDSCs.

Abbreviations: HSC, hematopoietic stem cells; CMP, common myeloid progenitor; GMP,granulocyte-macrophage progenitor; MDP, macrophage/dendritic cell progenitors; MDSCs, myeloid-derived suppressor cells; M-MDSCs, monocytic myeloid-derived suppressor cells; PMN-MDSCs, polymorphonuclear myeloid-derived suppressor cells; GM-CSF, granulocyte-macrophage colony-stimulating factor; M-CSF, macrophage colony-stimulating factor; VEGF, vascular endothelial growth factor; G-CSF, granulocyte colony-stimulating factor; SCF, stem cell factor; IFN- $\gamma$, interferon- $\gamma$; PGE2, prostaglandin E2; ARGI, arginase; IDO, indoleamine 2,3-dioxygenase; NO, nitric oxide; DC, dendritic cell, T, T cell; Treg, regulatory T cell; M $\phi$, macrophage; ENTPD2, ectonucleoside triphosphate diphosphohydrolase 2; CCLs, CC chemokine ligands; CXCLs, $\mathrm{C}-\mathrm{X}-\mathrm{C}$ chemokine ligands; TME, tumor microenvironment; iNOS, inducible nitric oxide synthase.

systemic chemotherapy in the treatment of HCC has been hampered by the inevitable toxicities associated with maximum tolerated dose-type chemotherapy and the poor toleration by patients with HCC because of impaired organ function and decreased bone marrow reserves.

Administration of chemotherapeutic agents in a lowdose and uninterrupted manner is referred to as metronomic chemotherapy. Metronomic chemotherapy was originally described as an antiangiogenic chemotherapy ${ }^{63}$ and has recently been demonstrated to modulate TME, including through an effect on the immune system. ${ }^{64,65}$ Notably, Servo et al demonstrated in a mouse melanoma model that an ultralow and nontoxic dose of paclitaxel could reduce MDSC numbers, improve immunosuppressive functions, and prolong the survival of tumor-bearing mice. ${ }^{53}$ Clinical studies of metronomic chemotherapy have been conducted in patients with advanced $\mathrm{HCC}$, mainly using oral 5-FU preparations either alone or in combination of 
antiangiogenic agents. ${ }^{66-69}$ Although the treatments were well tolerated by HCC patients, their RRs were only modest. These trials did not investigate whether metronomic chemotherapy affects MDSCs in circulation or TME.

Previous studies have shown that treatment with sunitinib, a multikinase inhibitor with antiangiogenic activity, decreased the number of circulating MDSCs in patients with cancer. ${ }^{70,71}$ Multiple preclinical studies have demonstrated that sunitinib was able to deplete the number of MDSCs in circulation as well as in tumors. ${ }^{72,73}$ Another preclinical study demonstrated that cabozantinib reduced intratumoral PMN-MDSCs and enhanced the therapeutic effect of ICIs in a prostate cancer model. ${ }^{74}$ With regard to the clinical efficacy in advanced HCC, sunitinib failed to provide similar clinical efficacy as sorafenib as a first-line therapy for advanced HCC in a phase III trial, ${ }^{75}$ whereas cabozantinib demonstrated significant survival benefits compared with a placebo in patients with HCC who had been previously treated with sorafenib and became an approved agent for advanced HCC. ${ }^{8}$

A recent preclinical study demonstrated that MDSCs could be selectively targeted by TRAIL receptor 2 (TRAIL-R2/DR5) agonist. ${ }^{76}$ A phase I trial testing the agonistic TRAIL-R2 antibody DS-8273a in patients with advanced cancer, including HCC, found that DS-8273a eliminated MDSCs without affecting mature myeloid or lymphoid cells, and the decrease in MDSCs was associated with progression-free survival (PFS). ${ }^{77}$ Another randomized phase II study evaluated tigatuzumab, a humanized monoclonal antibody directed against TRAIL-R2, in patients with advanced HCC. ${ }^{78}$ Although patients treated with tigatuzumab plus sorafenib had numerically longer median PFS and overall survival than those treated with sorafenib alone, the differences did not reach statistical significance. The combination of tigatuzumab with sorafenib was well tolerated in patients with HCC; however, the effect on MDSCs was not investigated.

Another strategy to reduce the number of MDSCs in TME is to facilitate MDSCs differentiating into dendritic cells and macrophages. This MDSC differentiation strategy can be achieved through the inhibition of retinoic acid signaling using all-trans retinoid acid (ATRA). ${ }^{79}$ ATRA has been determined in clinical trials to downregulate MDSCs, and a significant reduction of MDSCs was observed in patients with renal cell carcinoma and smallcell lung cancer. ${ }^{80,81} \mathrm{~A}$ case report by Hungarian investigators detailed how a patient received ATRA treatment for hematological malignancy and experienced significant tumor remission in liver tumors, which were clinically diagnosed as HCC because of moderately elevated alfa-fetoprotein and the presence of portal vein thrombosis. $^{82}$ In addition, polyprenoid acid, a synthetic retinoid derivative, has been demonstrated to prevent second primary HCCs in patients who underwent surgical resection for $\mathrm{HCC}{ }^{83,84}$ Polyprenoid acid may work through multiple mechanisms to achieve its chemopreventive effect on HCC. ${ }^{85,86}$ However, whether it would affect anticancer immunity or MDSCs is unclear.

\section{Blockade of MDSC trafficking}

Entry of MDSCs into TME is critical for their main immunosuppressive function to be manifested. Therefore, inhibiting chemokine receptors may reduce the number of MDSCs in TME. Chemokine receptor CCR2 and the interaction of its ligand CCL2 are required not only for the recruitment of M-MDSCs and tumor-associated macrophages but also for their suppressive function. ${ }^{87,88}$ A CCR2 inhibitor, PF04136309, has been tested in combination with FOLFIRINOX chemotherapy in a phase $\mathrm{Ib}$ clinical trial of patients with advanced pancreatic cancer. Compared with patients who received FOLFIRINOX alone, those who received chemotherapy plus PF-04136309 had a significantly lower ratio of blood to bone marrow CCR2positive monocytes, demonstrating the effect of CCR2 blockade on the inhibition of the mobilization of bone marrowderived monocytes into circulation. ${ }^{89}$

CCR5 is another chemokine receptor that is expressed in many immune cells, and the CCR5-CCR5 ligand axis was found to be critical for the mobilization of PMNMDSCs. ${ }^{90}$ Targeting CCR5 ${ }^{+}$MDSCs has been demonstrated to prevent MDSC migration and suppress tumor growth in preclinical studies. ${ }^{91,92}$ Recently, a phase $\mathrm{Ib} / 2$ clinical trial testing a small-molecule CCR2/5 dual antagonist, BMS-813160, as monotherapy or in combination with chemotherapy or nivolumab in patients with advanced pancreatic or colorectal cancer began to recruit patients. $^{93}$ CXCR2 is another chemokine receptor expressed on PMN-MDSCs and tumor-associated neutrophils. Blocking CXCR2 has limited the recruitment of PMN-MDSCs and enhanced the efficacy of anti-PD-1 therapy or chemotherapy in preclinical studies. ${ }^{94,95}$ However, there has been no clinical development of inhibitors of these chemokine receptors in HCC. 


\section{Inhibition of the immunosuppressive function of MDSCs}

STAT3 is a critical transcription factor for immunosuppressive activity and proliferation of MDSCs. A STAT3 oligonucleotide inhibitor, danvatirsen (AZD9150), was tested in a phase I clinical trial of patients with advanced HCC (NCT01839604); 39 patients with HCC actually received the study agent in the escalation or expansion cohort, and only one patient in the escalation cohort had a partial response. The most common adverse events were transaminase elevation and thrombocytopenia. ${ }^{96}$ In a recent phase $\mathrm{Ib} / 2$ study testing danvatirsen with or without durvalumab, an anti-PD-L1 antibody, in patients with head and neck squamous cell carcinoma (HNSCC), no responses were reported to monotherapy with danvatirsen; however, a relatively high RR of $23 \%$ was reported in the danvatirsen plus durvalumab combination arm. $^{97}$

Histone deacetylase (HDAC) inhibitors may suppress MDSC function by reducing ARG1, iNOS, and COX-2 levels. ${ }^{98}$ Entinostat, a class I HDAC inhibitor, was demonstrated to inhibit the immunosuppressive function of both PMN-MDSCs and M-MDSCs in lung cancer and renal cancer mouse models. The antitumor effect of PD-1 blockade was also enhanced by adding entinostat in vivo. ${ }^{98}$ Several clinical trials have tested various HDAC inhibitors in HCC. ${ }^{99,100}$ Although these agents were generally tolerated, their activities as single-agent appeared to be low because of low RRs and short PFS. Further, the effect of such therapy on MDSCs was not evaluated.

Phosphodiesterase-5 (PDE-5) inhibition downregulated ARG1 and iNOS activities in several preclinical models. ${ }^{101-}$ ${ }^{103}$ Tadalafil, the FDA-approved PDE-5 inhibitor, has been tested in HCC mouse models; MDSC suppressor function was reversed and the antitumor effect of cytokine-induced killer-cell therapy was enhanced by the addition of tadalafil. ${ }^{103}$ Tadalafil has been tested in clinical trials of patients with HNSCC and melanoma, but not in patient with HCC. The treatment was well tolerated, MDSCs were suppressed in circulation and tumor tissues, and T cell immunity was determined to be elevated. ${ }^{104-106}$

\section{Targeting MDSCs in the treatment of HCC: future perspectives}

Ensuring that the targeting MDSCs is a clinically useful therapy is challenging because of the following reasons. First, MDSCs are a heterogeneous group of immature myeloid cells that require multiple markers to define and differentiate their subtypes. In humans, no single-specific marker exists for defining MDSCs or their subtypes. This limitation makes direct demonstration of MDSCs in human HCC tumors and tracking their dynamic changes in humans cumbersome. Lack of specific makers also renders the development of "targeted therapy" for specifically targeting MDSCs difficult in humans. Second, although multiple therapeutic strategies focusing on depleting, inhibiting the trafficking, and downregulating the immunosuppressive function of MDSCs have been proposed in preclinical models, most agents have exhibited multiple biological functions, thereby making the true contribution of targeting MDSCs to therapeutic effects less convincing. Third, the clinical data of potential MDSCstargeting agents, revealed by preclinical studies, suggest that these strategies when administered alone are of limited efficacy against HCC.

Therefore, future studies should focus on identifying specific markers of and developing reliable assays for detecting human MDSCs and their subtypes. Specific markers will be invaluable for helping to develop more specific approaches for targeting MDSCs. Assays that could reliably detect MDSCs in both circulation and tissues, and in freshly prepared and archival samples, are of great importance for confirming the significance of MDSCs in patients with HCC who undergo therapeutic approaches. Furthermore, future studies should focus on developing combined approaches for treating HCC, especially those that incorporate MDSC-targeting therapy with ICIs or antiangiogenic agents, the two approved therapeutic strategies for treating HCC.

In conclusion, MDSCs play critical roles in promoting immunosuppression and angiogenesis, two major "cancer hallmarks" and two crucial therapeutic targets for HCC. The prognostic significance of MDSCs has been demonstrated in multiple clinical studies of patients with HCC. Thus, targeting MDSCs may be a potential therapeutic strategy for treating HCC. Although multiple preclinical studies have demonstrated the promising therapeutic efficacy of targeting MDSCs, additional well-designed clinical studies incorporating strong immunological, molecular, and biochemical research are warranted for the successful development of targeting MDSCs in the treatment of HCC.

\section{Acknowledgments}

This study was supported by grants from the Ministry of Science and Technology, Taiwan (MOST 105-2314-B-002186-MY3, 106-2314-B-002-210, 107-3017-F-002-002, and 
108-3017-F-002-004) and the Ministry of Education, Taiwan (NTU-108L901403).

\section{Disclosure}

Dr Chih-Hung Hsu reports grants from the Ministry of Science and Technology, Taiwan, during the conduct of the study; personal fees were received from Ono Pharmaceutical, BMS, MSD, and Eli Lilly, outside the submitted work. All authors report no other conflicts on interest in this work.

\section{References}

1. Bray F, Ferlay J, Soerjomataram I, Siegel RL, Torre LA, Jemal A. Global cancer statistics 2018: GLOBOCAN estimates of incidence and mortality worldwide for 36 cancers in 185 countries. $C A$ Cancer J Clin. 2018;68(6):394-424. doi:10.3322/caac.21492

2. Hsiue EH-CH, Lo W-C, Lin -H-H, Hsu C-H, Cheng A-L. Abstract 286: forecast of the incidence and etiology of liver cancer in Taiwan, Japan, United States, and United Kingdom: toward harmonization of East and West. Cancer Res. 2017;77(13 Supplement):286. doi:10.1158/15387445.AM2017-286

3. Forner A, Reig M, Bruix J. Hepatocellular carcinoma. Lancet. 2018;391(10127):1301-1314. doi:10.1016/S0140-6736(18)30010-2

4. Llovet JM, Ricci S, Mazzaferro V, et al. Sorafenib in advanced hepatocellular carcinoma. N Engl J Med. 2008;359(4):378-390. doi:10.1056/NEJMoa0708857

5. Cheng AL, Kang YK, Chen Z, et al. Efficacy and safety of sorafenib in patients in the Asia-Pacific region with advanced hepatocellular carcinoma: a phase III randomised, double-blind, placebo-controlled trial. Lancet Oncol. 2009;10(1):25-34. doi:10.1016/S1470-2045(08)70285-7

6. Bruix J, Qin S, Merle P, et al. Regorafenib for patients with hepatocellular carcinoma who progressed on sorafenib treatment (RESORCE): a randomised, double-blind, placebo-controlled, phase 3 trial. Lancet. 2017;389(10064):56-66. doi:10.1016/S0140-6736(16)32453-9

7. Kudo M, Finn RS, Qin S, et al. Lenvatinib versus sorafenib in first-line treatment of patients with unresectable hepatocellular carcinoma: a randomised phase 3 non-inferiority trial. Lancet. 2018;391(10126):1163-1173. doi:10.1016/S0140-6736(18)30207-1

8. Abou-Alfa GK, Meyer T, Cheng AL, et al. Cabozantinib in patients with advanced and progressing hepatocellular carcinoma. $N$ Engl $J$ Med. 2018;379(1):54-63. doi:10.1056/NEJMoa1717002

9. Zhu AX, Kang Y-K, Yen C-J, et al. REACH-2: a randomized, double-blind, placebo-controlled phase 3 study of ramucirumab versus placebo as second-line treatment in patients with advanced hepatocellular carcinoma (HCC) and elevated baseline alpha-fetoprotein (AFP) following first-line sorafenib. J Clin Oncol. 2018;36 (15_suppl):4003.

10. El-Khoueiry AB, Sangro B, Yau T, et al. Nivolumab in patients with advanced hepatocellular carcinoma (CheckMate 040): an open-label, non-comparative, phase 1/2 dose escalation and expansion trial. Lancet. 2017;389(10088):2492-2502. doi:10.1016/S0140-6736(17)31046-2.

11. Zhu AX, Finn RS, Edeline J, et al. Pembrolizumab in patients with advanced hepatocellular carcinoma previously treated with sorafenib (KEYNOTE-224): a non-randomised, open-label phase 2 trial. Lancet Oncol. 2018;19(7):940-952.

12. Khan KA, Kerbel RS. Improving immunotherapy outcomes with anti-angiogenic treatments and vice versa. Nat Rev Clin Oncol. 2018;15(5):310-324. doi:10.1038/nrclinonc.2018.9
13. Fukumura D, Kloepper J, Amoozgar Z, Duda DG, Jain RK. Enhancing cancer immunotherapy using antiangiogenics: opportunities and challenges. Nat Rev Clin Oncol. 2018;15(5):325-340. doi:10.1038/nrclinonc.2018.29

14. Xu J-M, Zhang Y, Jia R, et al. Anti-programmed death-1 antibody SHR-1210 (S) combined with apatinib (A) for advanced hepatocellular carcinoma (HCC), gastric cancer (GC) or esophagogastric junction (EGJ) cancer refractory to standard therapy: a phase 1 trial. J Clin Oncol. 2018;36(15_suppl):4075. doi:10.1200/ JCO.2018.36.15_suppl.4075

15. Ikeda M, Sung $\bar{M} W$, Kudo M, et al. A phase $1 \mathrm{~b}$ trial of lenvatinib (LEN) plus pembrolizumab (PEM) in patients (pts) with unresectable hepatocellular carcinoma (uHCC). J Clin Oncol. 2018;36 (15_suppl):4076. doi:10.1200/JCO.2018.36.15_suppl.4076

16. Stein S, Pishvaian MJ, Lee MS, et al. Safety and clinical activity of $1 \mathrm{~L}$ atezolizumab + bevacizumab in a phase Ib study in hepatocellular carcinoma (HCC). J Clin Oncol. 2018;36(15_suppl):4074. doi:10.1200/JCO.2018.36.15_suppl.4074

17. Gabrilovich DI. Myeloid-derived suppressor cells. Cancer Immunol Res. 2017;5(1):3-8. doi:10.1158/2326-6066.CIR-16-0297

18. Bronte V, Brandau S, Chen SH, et al. Recommendations for myeloid-derived suppressor cell nomenclature and characterization standards. Nat Commun. 2016;7:12150. doi:10.1038/ ncomms 12150

19. Condamine T, Dominguez GA, Youn JI, et al. Lectin-type oxidized LDL receptor-1 distinguishes population of human polymorphonuclear myeloid-derived suppressor cells in cancer patients. Sci Immunol. 2016;1:2. doi:10.1126/sciimmunol.aah6817

20. Gabrilovich DI, Nagaraj S. Myeloid-derived suppressor cells as regulators of the immune system. Nat Rev Immunol. 2009;9 (3):162-174. doi:10.1038/nri2506

21. Murdoch C, Muthana M, Coffelt SB, Lewis CE. The role of myeloid cells in the promotion of tumour angiogenesis. Nat Rev Cancer. 2008;8(8):618-631. doi:10.1038/nrc2444

22. Qu X, Zhuang G, Yu L, Meng G, Ferrara N. Induction of Bv8 expression by granulocyte colony-stimulating factor in CD11b+Gr1+ cells: key role of Stat3 signaling. J Biol Chem. 2012;287(23):19574-19584. doi:10.1074/jbc.M111.326801

23. Shojaei F, Wu X, Malik AK, et al. Tumor refractoriness to anti-VEGF treatment is mediated by $\mathrm{CD} 11 \mathrm{~b}+\mathrm{Gr} 1+$ myeloid cells. Nat Biotechnol. 2007;25(8):911-920. doi:10.1038/nbt1323

24. Shojaei F, Wu X, Qu X, et al. G-CSF-initiated myeloid cell mobilization and angiogenesis mediate tumor refractoriness to anti-VEGF therapy in mouse models. Proc Natl Acad Sci U SA. 2009;106(16):6742-6747. doi:10.1073/pnas.0902280106

25. Ahn GO, Brown JM. Matrix metalloproteinase-9 is required for tumor vasculogenesis but not for angiogenesis: role of bone marrow-derived myelomonocytic cells. Cancer Cell. 2008;13 (3):193-205. doi:10.1016/j.ccr.2007.11.032

26. Yang L, DeBusk LM, Fukuda K, et al. Expansion of myeloid immune suppressor Gr+CD11b+ cells in tumor-bearing host directly promotes tumor angiogenesis. Cancer Cell. 2004;6(4):409-421. doi:10.1016/j.ccr.2004.08.031

27. Lj P, Us G, Quaglia A, et al. Metabolic regulation of hepatitis B immunopathology by myeloid-derived suppressor cells. Nat Med. 2015;21(6):591-600. doi:10.1038/nm.3856

28. Goh CC, Roggerson KM, Lee HC, Golden-Mason L, Rosen HR, Hahn YS. Hepatitis C virus-induced myeloid-derived suppressor cells suppress NK cell IFN-gamma production by altering cellular metabolism via arginase-1. J Immunol. 2016;196(5):2283-2292. doi:10.4049/jimmunol.1501881

29. Tacke RS, Lee HC, Goh C, et al. Myeloid suppressor cells induced by hepatitis $\mathrm{C}$ virus suppress T-cell responses through the production of reactive oxygen species. Hepatology. 2012;55(2):343-353. doi:10.1002/hep. 24700 
30. Yao L, Abe M, Kawasaki K, et al. Characterization of liver monocytic myeloid-derived suppressor cells and their role in a murine model of non-alcoholic fatty liver disease. PLoS One. 2016;11(2): e0149948. doi:10.1371/journal.pone.0149948

31. Dandri M, Bockmann JH. The challenge of protecting without overprotecting: the two sides of myeloid-derived suppressor cells in hepatitis B viral infection. Hepatology. 2016;63(3):1043-1046. doi:10.1002/hep.28385

32. Duffy A, Zhao F, Haile L, et al. Comparative analysis of monocytic and granulocytic myeloid-derived suppressor cell subsets in patients with gastrointestinal malignancies. Cancer Immunol Immunother. 2013;62(2):299-307. doi:10.1007/s00262-012-1332-3

33. Hoechst B, Ormandy LA, Ballmaier M, et al. A new population of myeloid-derived suppressor cells in hepatocellular carcinoma patients induces $\mathrm{CD} 4(+) \mathrm{CD} 25(+) \mathrm{Foxp} 3(+) \quad \mathrm{T}$ cells. Gastroenterology. 2008;135(1):234-243. doi:10.1053/j.gastro.2008.03.020

34. Arihara F, Mizukoshi E, Kitahara M, et al. Increase in CD14 +HLA-DR-/low myeloid-derived suppressor cells in hepatocellular carcinoma patients and its impact on prognosis. Cancer Immunol Immunother. 2013;62(8):1421-1430. doi:10.1007/s00262-013-1447-1

35. Gao XH, Tian L, Wu J, et al. Circulating CD14(+) HLA-DR(-/low) myeloid-derived suppressor cells predicted early recurrence of hepatocellular carcinoma after surgery. Hepatol Res. 2017;47 (10):1061-1071. doi:10.1111/hepr.12831

36. Mizukoshi E, Yamashita T, Arai K, et al. Myeloid-derived suppressor cells correlate with patient outcomes in hepatic arterial infusion chemotherapy for hepatocellular carcinoma. Cancer Immunol Immunother. 2016;65(6):715-725. doi:10.1007/s00262-016-1837-2

37. Iwata T, Kondo Y, Kimura O, et al. PD-L1(+)MDSCs are increased in HCC patients and induced by soluble factor in the tumor microenvironment. Sci Rep. 2016;6:39296. doi:10.1038/srep39296

38. Hoechst B, Voigtlaender T, Ormandy L, et al. Myeloid derived suppressor cells inhibit natural killer cells in patients with hepatocellular carcinoma via the NKp30 receptor. Hepatology. 2009;50 (3):799-807. doi:10.1002/hep.23054

39. Kalathil S, Lugade AA, Miller A, Iyer R, Thanavala Y. Higher frequencies of GARP $(+)$ CTLA-4(+)Foxp3(+) T regulatory cells and myeloid-derived suppressor cells in hepatocellular carcinoma patients are associated with impaired T-cell functionality. Cancer Res. 2013;73 (8):2435-2444. doi:10.1158/0008-5472.CAN-12-3381

40. Nan J, Xing YF, Hu B, et al. Endoplasmic reticulum stress induced LOX-1(+) CD15(+) polymorphonuclear myeloid-derived suppressor cells in hepatocellular carcinoma. Immunology. 2018;154 (1):144-155. doi:10.1111/imm.12876

41. Kapanadze T, Gamrekelashvili J, Ma C, et al. Regulation of accumulation and function of myeloid derived suppressor cells in different murine models of hepatocellular carcinoma. J Hepatol. 2013;59 (5):1007-1013. doi:10.1016/j.jhep.2013.06.010

42. Hu CE, Gan J, Zhang RD, Cheng YR, Huang GJ. Up-regulated myeloid-derived suppressor cell contributes to hepatocellular carcinoma development by impairing dendritic cell function. Scand J Gastroenterol. 2011;46(2):156-164. doi:10.3109/00365521.2010.516450

43. Lacotte S, Slits F, Orci LA, et al. Impact of myeloid-derived suppressor cell on Kupffer cells from mouse livers with hepatocellular carcinoma. Oncoimmunology. 2016;5(11):e1234565. doi:10.1080/2162402X.2016.1234565

44. Chen Y, Huang Y, Reiberger T, et al. Differential effects of sorafenib on liver versus tumor fibrosis mediated by stromal-derived factor 1 alpha/ $\mathrm{C}-\mathrm{X}-\mathrm{C}$ receptor type 4 axis and myeloid differentiation antigen-positive myeloid cell infiltration in mice. Hepatology. 2014;59(4):1435-1447. doi: $10.1002 /$ hep. 26790

45. Chang CJ, Yang YH, Chiu CJ, et al. Targeting tumor-infiltrating Ly6G(+) myeloid cells improves sorafenib efficacy in mouse orthotopic hepatocellular carcinoma. Int $J$ Cancer. 2018;142 (9):1878-1889. doi:10.1002/ijc.31216
46. Chiu DK, Tse AP, Xu IM, et al. Hypoxia inducible factor HIF-1 promotes myeloid-derived suppressor cells accumulation through ENTPD2/CD39L1 in hepatocellular carcinoma. Nat Commun. 2017;8(1):517. doi:10.1038/s41467-017-00530-7

47. Zhou J, Liu M, Sun H, et al. Hepatoma-intrinsic CCRK inhibition diminishes myeloid-derived suppressor cell immunosuppression and enhances immune-checkpoint blockade efficacy. Gut. 2018;67 (5):931-944. doi:10.1136/gutjnl-2017-314032

48. Fleming V, Hu X, Weber R, et al. Targeting myeloid-derived suppressor cells to bypass tumor-induced immunosuppression. Front Immunol. 2018;9:398. doi:10.3389/fimmu.2018.00398

49. Medina-Echeverz J, Eggert T, Han M, Greten TF. Hepatic myeloid-derived suppressor cells in cancer. Cancer Immunol Immunother. 2015;64(8):931-940. doi:10.1007/s00262-015-1736-y

50. De Sanctis F, Solito S, Ugel S, Molon B, Bronte V, Marigo I. MDSCs in cancer: conceiving new prognostic and therapeutic targets. Biochim Biophys Acta. 2016;1865(1):35-48. doi:10.1016/j.bbcan.2015.08.001

51. Eriksson E, Wenthe J, Irenaeus S, Loskog A, Ullenhag G. Gemcitabine reduces MDSCs, tregs and TGFbeta- 1 while restoring the teff/treg ratio in patients with pancreatic cancer. $J$ Transl Med. 2016;14(1):282. doi:10.1186/s12967-016-0867-z

52. Alizadeh D, Trad M, Hanke NT, et al. Doxorubicin eliminates myeloid-derived suppressor cells and enhances the efficacy of adoptive T-cell transfer in breast cancer. Cancer Res. 2014;74 (1):104-118. doi:10.1158/0008-5472.CAN-13-1545

53. Sevko A, Michels T, Vrohlings M, et al. Antitumor effect of paclitaxel is mediated by inhibition of myeloid-derived suppressor cells and chronic inflammation in the spontaneous melanoma model. J Immunol. 2013;190(5):2464-2471. doi:10.4049/jimmunol.1202781

54. Vincent J, Mignot G, Chalmin F, et al. 5-Fluorouracil selectively kills tumor-associated myeloid-derived suppressor cells resulting in enhanced $\mathrm{T}$ cell-dependent antitumor immunity. Cancer Res. 2010;70(8):3052-3061. doi:10.1158/0008-5472.CAN-09-3690

55. Al C, Kh Y, Rl F, et al. Biochemical modulation of doxorubicin by high-dose tamoxifen in the treatment of advanced hepatocellular carcinoma. Hepatogastroenterology. 1998;45(24):1955-1960.

56. Yang TS, Lin YC, Chen JS, Wang HM, Wang CH. Phase II study of gemcitabine in patients with advanced hepatocellular carcinoma. Cancer. 2000;89(4):750-756.

57. Guan Z, Wang Y, Maoleekoonpairoj S, et al. Prospective randomised phase II study of gemcitabine at standard or fixed dose rate schedule in unresectable hepatocellular carcinoma. $\mathrm{Br} J$ Cancer. 2003;89(10):1865-1869. doi:10.1038/sj.bjc.6601369

58. Chao Y, Chan WK, Birkhofer MJ, et al. Phase II and pharmacokinetic study of paclitaxel therapy for unresectable hepatocellular carcinoma patients. Br J Cancer. 1998;78(1):34-39.

59. Lai CL, Wu PC, Chan GC, Lok AS, Lin HJ. Doxorubicin versus no antitumor therapy in inoperable hepatocellular carcinoma. A prospective randomized trial. Cancer. 1988;62(3):479-483.

60. Yeo W, Mok TS, Zee B, et al. A randomized phase III study of doxorubicin versus cisplatin/interferon alpha-2b/doxorubicin/fluorouracil (PIAF) combination chemotherapy for unresectable hepatocellular carcinoma. J Natl Cancer Inst. 2005;97(20):1532-1538. doi:10.1093/jnci/dji315

61. Gebbia V, Maiello E, Serravezza G, et al. 5-Fluorouracil plus high dose levofolinic acid and oral hydroxyurea for the treatment of primary hepatocellular carcinomas: results of a phase II multicenter study of the Southern Italy Oncology Group (G.O.I.M.). Anticancer Res. 1999;19(2B):1407-1410.

62. Patt YZ, Hassan MM, Lozano RD, et al. Phase II trial of systemic continuous fluorouracil and subcutaneous recombinant interferon Alfa-2b for treatment of hepatocellular carcinoma. J Clin Oncol. 2003;21(3):421-427. doi:10.1200/JCO.2003.10.103

63. Kerbel RS, Kamen BA. The anti-angiogenic basis of metronomic chemotherapy. Nat Rev Cancer. 2004;4(6):423-436. doi:10.1038/ nrc1369 
64. Chan TS, Hsu CC, Pai VC, et al. Metronomic chemotherapy prevents therapy-induced stromal activation and induction of tumor-initiating cells. $J$ Exp Med. 2016;213(13):2967-2988. doi:10.1084/jem.20151665

65. Andre N, Tsai K, Carre M, Pasquier E. Metronomic chemotherapy: direct targeting of cancer cells after all? Trends Cancer. 2017;3 (5):319-325. doi:10.1016/j.trecan.2017.03.011

66. Abdel-Rahman O, Abdel-Wahab M, Shaker M, Abdel-Wahab S, Elbassiony M, Ellithy M. Sorafenib versus capecitabine in the management of advanced hepatocellular carcinoma. Med Oncol. 2013;30(3):655. doi:10.1007/s12032-013-0655-Z

67. Hsu CH, Shen YC, Lin ZZ, et al. Phase II study of combining sorafenib with metronomic tegafur/uracil for advanced hepatocellular carcinoma. J Hepatol. 2010;53(1):126-131. doi:10.1016/j.jhep.2010.01.035

68. Hsu CH, Yang TS, Hsu C, et al. Efficacy and tolerability of bevacizumab plus capecitabine as first-line therapy in patients with advanced hepatocellular carcinoma. Br J Cancer. 2010;102 (6):981-986. doi:10.1038/sj.bjc.6605580

69. Shao YY, Lin ZZ, Hsu C, et al. Efficacy, safety, and potential biomarkers of thalidomide plus metronomic chemotherapy for advanced hepatocellular carcinoma. Oncology. 2012;82(1):59-66. doi:10.1159/000336126

70. Ko JS, Zea AH, Rini BI, et al. Sunitinib mediates reversal of myeloid-derived suppressor cell accumulation in renal cell carcinoma patients. Clin Cancer Res. 2009;15(6):2148-2157. doi:10.1158/1078-0432.CCR-08-1332

71. Chen HM, Ma G, Gildener-Leapman N, et al. Myeloid-derived suppressor cells as an immune parameter in patients with concurrent sunitinib and stereotactic body radiotherapy. Clin Cancer Res. 2015;21(18):4073-4085. doi:10.1158/1078-0432.CCR-14-2742

72. Draghiciu O, Nijman HW, Hoogeboom BN, Meijerhof T, Daemen T. Sunitinib depletes myeloid-derived suppressor cells and synergizes with a cancer vaccine to enhance antigen-specific immune responses and tumor eradication. Oncoimmunology. 2015; (3):e989764. doi:10.1080/2162402X.2015.1008371

73. Ozao-Choy J, Ma G, Kao J, et al. The novel role of tyrosine kinase inhibitor in the reversal of immune suppression and modulation of tumor microenvironment for immune-based cancer therapies. Cancer Res. 2009;69(6):2514-2522. doi:10.1158/0008-5472.CAN08-4709

74. Lu X, Horner JW, Paul E, et al. Effective combinatorial immunotherapy for castration-resistant prostate cancer. Nature. 2017;543 (7647):728-732. doi:10.1038/nature21676

75. Cheng AL, Kang YK, Lin DY, et al. Sunitinib versus sorafenib in advanced hepatocellular cancer: results of a randomized phase III trial. J Clin Oncol. 2013;31(32):4067-4075. doi:10.1200/JCO.2012.45.8372

76. Condamine T, Kumar V, Ramachandran IR, et al. ER stress regulates myeloid-derived suppressor cell fate through TRAIL-R-mediated apoptosis. J Clin Invest. 2014;124 (6):2626-2639. doi:10.1172/JCI74056

77. Dominguez GA, Condamine T, Mony S, et al. Selective targeting of myeloid-derived suppressor cells in cancer patients using DS-8273a, an agonistic TRAIL-R2 antibody. Clin Cancer Res. 2017;23(12):2942-2950. doi:10.1158/1078-0432.CCR-16-1784

78. Cheng AL, Kang YK, He AR, et al. Safety and efficacy of tigatuzumab plus sorafenib as first-line therapy in subjects with advanced hepatocellular carcinoma: a phase 2 randomized study. $J$ Hepatol. 2015;63(4):896-904. doi:10.1016/j.jhep.2015.06.001

79. Nefedova Y, Fishman M, Sherman S, Wang X, Beg AA, Gabrilovich DI. Mechanism of all-trans retinoic acid effect on tumor-associated myeloid-derived suppressor cells. Cancer Res. 2007;67 (22):11021-11028. doi:10.1158/0008-5472.CAN-07-2593

80. Mirza N, Fishman M, Fricke I, et al. All-trans-retinoic acid improves differentiation of myeloid cells and immune response in cancer patients. Cancer Res. 2006;66(18):9299-9307. doi:10.1158/ 0008-5472.CAN-06-1690
81. Iclozan C, Antonia S, Chiappori A, Chen DT, Gabrilovich D. Therapeutic regulation of myeloid-derived suppressor cells and immune response to cancer vaccine in patients with extensive stage small cell lung cancer. Cancer Immunol Immunother. 2013;62(5):909-918. doi:10.1007/s00262-013-1396-8

82. Egyed M, Nyaradi A, Boros B, et al. [Successful treatment of hepatocellular carcinoma with All-trans-retinoic acid]. Orv Hetil. 1998;139(14):811-812.

83. Muto Y, Moriwaki H, Ninomiya M, et al. Prevention of second primary tumors by an acyclic retinoid, polyprenoic acid, in patients with hepatocellular carcinoma. Hepatoma Prevention Study Group. N Engl J Med. 1996;334(24):1561-1567. doi:10.1056/NEJM199606133342402

84. Muto Y, Moriwaki H, Saito A. Prevention of second primary tumors by an acyclic retinoid in patients with hepatocellular carcinoma. $N$ Engl J Med. 1999;340(13):1046-1047. doi:10.1056/NEJM199904013401315

85. Takai K, Okuno M, Yasuda I, et al. Prevention of second primary tumors by an acyclic retinoid in patients with hepatocellular carcinoma. Updated analysis of the long-term follow-up data. Intervirology. 2005;48(1):39-45.

86. Shimizu M, Imai K, Takai K, Moriwaki H. Role of acyclic retinoid in the chemoprevention of hepatocellular carcinoma: basic aspects, clinical applications, and future prospects. $\mathrm{Curr}$ Cancer Drug Targets. 2012;12(9):1119-1128.

87. Ugel S, De Sanctis F, Mandruzzato S, Bronte V. Tumor-induced myeloid deviation: when myeloid-derived suppressor cells meet tumor-associated macrophages. J Clin Invest. 2015;125(9):3365-3376.

88. Lesokhin AM, Hohl TM, Kitano S, et al. Monocytic CCR2(+) myeloid-derived suppressor cells promote immune escape by limiting activated CD8 T-cell infiltration into the tumor microenvironment. Cancer Res. 2012;72(4):876-886.

89. Nywening TM, Wang-Gillam A, Sanford DE, et al. Targeting tumour-associated macrophages with CCR2 inhibition in combination with FOLFIRINOX in patients with borderline resectable and locally advanced pancreatic cancer: a single-centre, open-label, dose-finding, non-randomised, phase 1b trial. Lancet Oncol. 2016;17(5):651-662.

90. Karin N, Razon H. The role of CCR5 in directing the mobilization and biological function of CD11b(+)Gr1(+)Ly6C(low) polymorphonuclear myeloid cells in cancer. Cancer Immunol Immunother. 2018;67(12):1949-1953.

91. Blattner C, Fleming V, Weber R, et al. CCR5(+) myeloid-derived suppressor cells are enriched and activated in melanoma lesions. Cancer Res. 2018;78(1):157-167.

92. Hawila E, Razon H, Wildbaum G, et al. CCR5 directs the mobilization of $\mathrm{CD} 11 \mathrm{~b}(+) \mathrm{Gr} 1(+) \mathrm{Ly} 6 \mathrm{C}($ low) polymorphonuclear myeloid cells from the bone marrow to the blood to support tumor development. Cell Rep. 2017;21(8):2212-2222.

93. Le D, Gutierrez ME, Saleh M, et al. Abstract CT124: a phase Ib/II study of BMS-813160, a CC chemokine receptor (CCR) 2/ 5 dual antagonist, in combination with chemotherapy or nivolumab in patients (pts) with advanced pancreatic or colorectal cancer. Cancer Res. 2018;78(13 Supplement):CT124-CT124.

94. Highfill SL, Cui Y, Giles AJ, et al. Disruption of CXCR2-mediated MDSC tumor trafficking enhances anti-PD1 efficacy. Sci Transl Med. 2014;6(237):237ra267.

95. Nywening TM, Belt BA, Cullinan DR, et al. Targeting both tumour-associated CXCR2 $(+)$ neutrophils and CCR2 $(+)$ macrophages disrupts myeloid recruitment and improves chemotherapeutic responses in pancreatic ductal adenocarcinoma. Gut. 2018;67(6):1112-1123.

96. ClincalTrials.gov. [Updated March 6, 2017; cited December 14, 2018]. Available from: https://clinicaltrials.gov/ct2/show/study/ NCT01839604. Accessed December 14, 2018.

97. Cohen EEW, Harrington KJ, Hong DS, et al. 1044OA phase Ib/II study (SCORES) of durvalumab (D) plus danvatirsen (DAN; AZD9150) or AZD5069 (CX2i) in advanced solid malignancies and recurrent/metastatic head and neck squamous cell carcinoma (RM-HNSCC): updated results. Ann Oncol. 2018;29(suppl_8):mdy287. 
98. Orillion A, Hashimoto A, Damayanti N, et al. Entinostat neutralizes myeloid-derived suppressor cells and enhances the antitumor effect of PD-1 inhibition in murine models of lung and renal cell carcinoma. Clin Cancer Res. 2017;23(17):5187-5201.

99. Yeo W, Chung HC, Chan SL, et al. Epigenetic therapy using belinostat for patients with unresectable hepatocellular carcinoma: a multicenter phase I/II study with biomarker and pharmacokinetic analysis of tumors from patients in the Mayo Phase II Consortium and the Cancer Therapeutics Research Group. J Clin Oncol. 2012;30(27):3361-3367.

100. Bitzer M, Horger M, Giannini EG, et al. Resminostat plus sorafenib as second-line therapy of advanced hepatocellular carcinoma - the SHELTER study. J Hepatol. 2016;65(2):280-288. doi:10.1016/j. jhep.2016.02.043

101. Serafini P, Meckel K, Kelso M, et al. Phosphodiesterase-5 inhibition augments endogenous antitumor immunity by reducing myeloid-derived suppressor cell function. $J$ Exp Med. 2006;203(12):2691-2702. doi:10.1084/jem.20061104
102. Lin S, Wang J, Wang L, et al. Phosphodiesterase-5 inhibition suppresses colonic inflammation-induced tumorigenesis via blocking the recruitment of MDSC. Am J Cancer Res. 2017;7(1):41-52.

103. Yu SJ, Ma C, Heinrich B, et al. Targeting the crosstalk between cytokine-induced killer cells and myeloid-derived suppressor cells in hepatocellular carcinoma. J Hepatol. 2018. Epub ahead of print. doi:10.1016/j.jhep.2018.10.040

104. Weed DT, Vella JL, Reis IM, et al. Tadalafil reduces myeloid-derived suppressor cells and regulatory $\mathrm{T}$ cells and promotes tumor immunity in patients with head and neck squamous cell carcinoma. Clin Cancer Res. 2015;21(1):39-48. doi:10.1158/1078-0432.CCR-14-1711

105. Califano JA, Khan Z, Noonan KA, et al. Tadalafil augments tumor specific immunity in patients with head and neck squamous cell carcinoma. Clin Cancer Res. 2015;21(1):30-38. doi:10.1158/1078-0432.CCR-14-1716

106. Hassel JC, Jiang $\mathrm{H}$, Bender $\mathrm{C}$, et al. Tadalafil has biologic activity in human melanoma. Results of a pilot trial with Tadalafil in patients with metastatic Melanoma (TaMe). Oncoimmunology. 2017;6(9):e1326440. doi:10.1080/2162402X.2017.1326440
Journal of Hepatocellular Carcinoma

\section{Publish your work in this journal}

The Journal of Hepatocellular Carcinoma is an international, peerreviewed, open access journal that offers a platform for the dissemination and study of clinical, translational and basic research findings in this rapidly developing field. Development in areas including, but not limited to, epidemiology, vaccination, hepatitis therapy, pathology

\section{Dovepress}

and molecular tumor classification and prognostication are all considered for publication. The manuscript management system is completely online and includes a very quick and fair peer-review system, which is all easy to use. Visit http://www.dovepress.com/ testimonials.php to read real quotes from published authors. 